\title{
The use of drama to develop English speaking autonomous learning
}

\author{
Faizal Risdianto ${ }^{1}$, Sari Famularsih ${ }^{2}$, Setia Rini ${ }^{3}$, and Ahmad Mifdlol Muthohar ${ }^{4}$ \\ \{faizalrisdianto@iainsalatiga.ac.id' ${ }^{1}$, sarifamularsih@yahoo.com², \\ setiarini.setia@gmail.com ${ }^{3}$,mifdlol@gmail.com ${ }^{4}$ \} \\ ${ }^{1,2,3,4}$ IAIN Salatiga, Indonesia
}

\begin{abstract}
For several years there has been an appreciation and huge awareness pertaining to the importance autonomy of learners and the role of individual and group learners in leading their process of learning inside and outside the classroom. Nevertheless, in real teaching and learning process, it is not always visible how to encourage and develop learners dealing with this role, and how to ensure they are ready to perform it. The topic of autonomy of learners is widely discussed and acknowledged among social scientists and observers but perhaps to its complex and myriad characteristics, the autonomy of learners has not been studied widely up to present day. To fill this gap, this qualitative research was conducted to investigate the use of drama to build autonomous English learning towards the students of International class program of IAIN Salatiga batch 2018. There are twenty students of fourth semester along with the range of age between 19 and 20 years old as the subject of the research along with two problem statements: the first, how is the process of students' autonomous English learning process before and after the implementation of drama performance in the class? The second, what are the Strength and the weakness of the use of drama to improve autonomous English learning process of students? After conducting fourteen meeting of implementing the drama performance there were two conclusions: the first, it can be concluded that the use of drama performance is an effective method to develop autonomous learning habit of students. They are able to develop their potential in maximum way and be able to learn together in their peer learning group. The second, from the given questionnaire's answers, dealing with the strength of the use of drama in improving student's autonomous learning, it can be seen that there are 16 students who felt that drama performance can improve students' speaking ability, mastery of vocabulary and boost their self-confidence. Pertaining to the weakness of the use of drama in building autonomous learning there are 17 students who said that there is no weakness in the use of drama to build autonomous learning.
\end{abstract}

Keywords: drama, autonomous learning, English speaking skills. 


\section{INTRODUCTION}

For several years there has been the appreciation and great awareness pertaining to the importance autonomy of learners and the role of individual and group learners in leading their process of learning inside and outside the classroom[1][2][3][4]. Nevertheless, in real teaching and learning process, it is not always visible how to encourage and develop learners dealing with this role, and how to ensure they are ready to perform it. This paper developed some of the pedagogical aspects related to the development of autonomy of English learners and proposes a framework of models and skills that could be used by educators as a guide to improve students' autonomous learning responsibility. Although this framework was elaborated and enhanced in English language teaching context, its underlying theories apply to all walks of educational settings

The learner and learning-centered methods and approaches have considerable and influential role in today's teaching and learning process. Learners are viewed as the active interpreters and processers of knowledge who look for knowledge and competence based on their own orientations and needs. [5][6][7][8][9]. This means, it is the learners' autonomy to take control and responsibility of their own learning which ushered to three important arguments. Firstly, autonomous learners are more efficient and effective learners. They direct theirinner motivation, metacognitive strategy, and awareness as the doer and experiencer of the learning process. Secondly, being able to be autonomous learner implies the learner is lifelong learning which able to manage his own learning process and having responsibility of information mastery. Thirdly, autonomy learner implies vigorous and mindful participation in the community, which leads to further community development on bigger quality and resulting on individual's communal appreciation[10][11].The topic of autonomy of learners is widely discussed and acknowledged among social scientists and observers but perhaps to its complex and myriad quality, the autonomy of learners has not been studied widely up to present day[12][13][14].

This study particularly focused on students' process of autonomous learning particularly the implementation and perceptions of learner's autonomy in the context of English teaching in International class program (ICP) batch 2018 in State Institute of Islamic Studies Salatiga, Central Java, Indonesia through drama class. The subject of research age range between 19 and 20 years old.

The purpose of this this research was to enhance students' autonomous learning of speaking skills inside and outside the classroom, andto measure the extent of learner autonomy in the perspective of their performance, learning process and degree of autonomy and it also map students perception pertaining to the use of drama to improve English autonomous learning. It is in line withthe sparking idea that autonomy in the efforts of developing the conducive atmosphere conducive of living environment within the given educational system which gave the possibility of learners to be actively and vigorously involved in their English speaking learning process. In order to achieve the best result of learning, learners need to be made aware of their purpose of learning and how to develop it.

In this perspective, it does not mean that by the implementation of autonomous learning, the teacher's suggestion and back up is not necessary. In contradiction, the educator's role may alter, prefer to be a mediator than a knowledge specialist, or "the master" of wisdom and English teaching materials who convey information to students and it is undeniable that by means of classroom living activity that educators are able to cherish and guide them to be aware and learn to revitalize their individual and group independent skills. It is impossible that learners are able to have mastery over the resolution of, for instance, what to learn or how, 
except they have some level of encouragement to perform all the learning objective and except they are vigorous or enthusiastic their learning process and no one force them to do so.In short, learner's autonomy consists of self-motivation, enthusiasm, self-consciousness and mutual interaction within peer group[15] [16]

\section{METHODOLOGY}

This research was descriptive qualitative research. The frame work of this research used the assumption that learners not only work independently but in cooperation in social group [17] [18] The data were collected by having observation, documentation and giving questioners to the subject of the research. Pertaining to the questionnaires, they were given before and after the use of drama performance in the class.In this study, the researcher analyzed the students' oral production in the process of implementing drama speaking class in terms of verbal components of drama which was pronunciation, fluency, articulation and accuracy (grammar \& vocabulary).The subject of this research was ICP (International Class Program) of IAIN Salatiga batch 2018/2019 that consists of 20 students. The subject was purposely chosen since it was considered as the best class and expected to follow the learning activity attractively than other regular classes. In this research, the researcher used instruments such as scoring sheet for students' speaking performance, recording and transcription. In this qualitative research, the researcher analyzed the students' application of verbal components of drama in terms of articulation, pronunciation, fluency, and accuracy (grammar \& vocabulary).In analyzing the data, the researcher and another rater that was an English lecturer tried to investigate the students' speaking production by the use of drama to avoid subjectivity

\section{RESULT AND DISCUSSION}

The implementation of the use of drama to develop English autonomous learning was monitored through fourteen meetings. First meeting the lecturer and at the same time the researcher, explained the introduction and elaborated all elements of drama and then gave example of flash fiction entitled 'Candy' for students to analyze its content. Second meeting, four pictures with different topics was given to develop thelearner's ability in developing story line. Third meeting, the researcher showed the common mistake such as grammatical error and wrong diction made by students in drama script writing from previous meeting and the researcher helped the learners to improve their writing and vocabulary mastery. Fourth meeting, the students practiced character improvisation by making body language and expression of particular given situation. The fifth to ninth meetings are drama performances by the first, second, third, fourth, and fifth groups. The performances showed their lack and their progress made in vocabulary mastery and wrong spelling. The tenth until the fourteen meeting is the learning progress and the submission of group video of drama performance.

Within several meeting students were asked to fill the questionnaire which resulted that almost all students could apply each verbal components and they were given chance in enjoyably speaking practice in a different role part by the use of drama performance. Drama class motivated and gave chances to the students to learn a realistic meaningful communication. It means that students are able to communicate English dialogue in their performancealthough they still have weaknesses in their performance such as fluency and accuracy. Cheng elaborates that reciprocal or conjoint dramas are good technique and model of language gaining knowledge wherein in which each pupils in the class boost their 
autonomous learning competence and takes different role with specific goals and then got interacts with other students in the class to build alliances and complete common objective of learning[9].

The drama performance is able to improve and develop the feeling of self-confidence and remove student's mood of hesitation, because in drama activities, the students will have different role and responsibility. Both students active participation and assistance from the lecturer support in succeeding the learner autonomy. So, it is appropriate to use drama in developing students' autonomous learning.

\section{CONCLUSION}

From this research, it can be concluded that the use of drama performance to build learners autonomoud learning in this study had two results. After conducting fourteen meeting of implementing the drama performance there were two conclusions: the first, it can be concluded that the use of drama performance is an effective method to develop autonomous learning habit of students. They are able to develop their potential in maximum way and be able to learn together in their peer learning group. The second, from the given questionnaire's answers, dealing with the strength of the use of drama in improving student's autonomous learning, it can be seen that there are 16 students who felt that drama performance can improve students' speaking ability, mastery of vocabulary and boost their self-confidence. Pertaining to the weakness of the use of drama in building autonomous learning there are 17 students who said that there is no weakness in the use of drama to build autonomous learning.

\section{REFERENCES:}

[1] A. G. Fuentes, "The use of drama in the teaching of English to young learners. A case study," pp. 320-329, 2010.

[2] A. G. Fuentes, "Break a Leg! The Use of Drama in the Teaching of English to Young Learners. A Case Study."

[3] R. Anita, "Fostering learner's autonomy in classroom: why not?," pp. 333-342, 2016.

[4] R. Godwin-Jones, "Emerging Technologies for Autonomous Language Learning," SiSAL J., 2011.

[5] C. P. Niemiec and R. M. Ryan, "Autonomy, competence, and relatedness in the classroom:Applying self-determination theory to educational practice," Theory Res. Educ., 2009.

[6] X. Gang, "A Case Study on the Effectiveness of Learner Autonomy in British and American Literature Study," Stud. Lit. Lang., vol. 10, no. 1, pp. 88-94, 2015.

[7] N. Nyoman Padmadewi, "Techniques of Promoting Autonomous Learning in the Classroom," J. Educ. Soc. Sci., vol. 3.

[8] A. KOÇAK and A. Kocak, "A study on learners' readiness for autonomous learning of English as a foreign language [Unpublished MA thesis]," no. September, p. 115, 2003.

[9] L. Kamberi, "Promoting Learner Autonomy in Foreign Language," pp. 24-26, 2013.

[10] H. Thị Thanh Hoà Vũ Thị Bích Đào Nguyễn Thị Thu Trang, "Improving Learner Autonomy in Language Learning through Drama-Based Project."

[11] "(PDF) Starring Roles: Learner Autonomy in Drama Activities." [Online]. Available: https://www.researchgate.net/publication/284484801_Starring_Roles_Learner_Autonom y_in_Drama_Activities. [Accessed: 28-Apr-2019].

[12] L. Carson, "The Role of Drama in Task-based Learning: Agency, Identity and 
Autonomy," Scenario, vol. 2012, no. 02, Dec. 2012.

[13] A. Talkowska -Wojciechowska, "World Scientific News The use of the internet in developing learner's autonomy," 2015.

[14] D. Haugh, "Fostering Learner Autonomy through Dramatized Role-Plays," Japan Assoc. Lang. Teach. Anthol. More Auton. You Ask.

[15] T. Ilona Moore, "Drama, History and Autonomy: an examination of teacher interventions and student autonomy in two drama contexts," 2008.

[16] H. Thị Thanh Hoà Vũ Thị Bích Đào Nguyễn Thị Thu Trang, M. D. A. N. Simulacrum, and M. Hasyim, "Improving Learner Autonomy in Language Learning through DramaBased Project."

[17] D. Little, "Language Learner Autonomy: Some Fundamental Considerations Revisited," Innov. Lang. Learn. Teach., vol. 1, no. 1, pp. 14-29, 2007.

[18] N. S. Lengkanawati, "Learner Autonomy in the Indonesian Efl Settings," Indones. J. Appl. Linguist., vol. 6, no. 2, p. 222, 2017. 